\title{
Differences in the rabbit uterine response to progesterone as influenced by growth hormone or prolactin
}

\author{
B. S. Chilton and J. C. Daniel, Jr \\ Department of Cell Biology and Anatomy, Texas Tech University Health Sciences Center, Lubbock, \\ TX 79430; and College of Sciences, Old Dominion University, Norfolk, VA 23508, U.S.A.
}

\begin{abstract}
Summary. The direct effect of growth hormone (GH) on the uterine response to progesterone was tested by using ovariectomized rabbits (at least 12 weeks) treated with $\mathrm{GH} ; \mathrm{GH}+$ progesterone; or progesterone alone. These results were compared with the effect of prolactin or prolactin + progesterone on the uterus. Prolactin treatment produced an increase $(P<0.01)$ in the endometrial surface area and restored cytosolic oestrogen and progesterone receptor concentrations to oestrous control values. The sequential treatment of does with prolactin + progesterone stimulated uteroglobin production to a concentration equal to that found in intact rabbits on Day 5 of pregnancy. In contrast, GH treatment had no effect on endometrial surface area, produced an increase in the concentration of cytosolic oestrogen receptor but did not produce an increase in the concentration of progesterone receptor. The sequential treatment of does with $\mathrm{GH}+$ progesterone failed to stimulate uteroglobin secretion above control (progesterone alone) values. It is concluded that the action of prolactin in the rabbit uterus is not generally somatogenic; rather, prolactin increases the concentration of progesterone receptor and thereby enhances the uterine response to progesterone.
\end{abstract}

\section{Introduction}

The rabbit uterus becomes refractory in its response to ovarian steroids when the interval between ovariectomy and hormone replacement is prolonged. Using uterine protein production as the criterion, little or no response to progesterone treatment could be elicited 12 weeks after ovariectomy (Daniel, 1980). However, the uterus of long-term ovariectomized rabbits will secrete uteroglobin again if the animal is sequentially treated with prolactin and progesterone (Daniel et al., 1984). Furthermore, prolactin treatment of ovariectomized rabbits resulted in an increase $(P<0.05)$ in the concentration of cytosolic oestrogen and progesterone receptors, restoring the concentrations to values found at oestrus. Prolactin therefore appears to act by modulating progesterone receptor activity.

Specific receptors for prolactin have been described in rabbit uterine membranes (Tamaya et al., 1980; Ohno, 1982) with characteristics similar to those found in mammary tissue, a known target organ for lactogenic hormones (Shiu \& Friesen, 1974). Specific ${ }^{125}$ I-labelled growth hormone binding has also been reported in uterine membranes from adult female rabbits (Posner et al., 1974) and growth hormone increases hepatic prolactin and oestrogen receptors in hypophysectomized female rats (Norstedt, 1982). It is therefore important to differentiate the potential inductive action of prolactin in the uterus from the effect of growth hormone.

\section{Materials and Methods}

Reagents and buffers. Reagents were purchased from the following sources: $\left[6,7-{ }^{3} \mathrm{H}(\mathrm{N})\right]$ oestradiol (sp. act. $52 \cdot 0 \mathrm{Ci} / \mathrm{mmol}), 17 \beta$-methyl- $\left[{ }^{3} \mathrm{H}\right]$ promegestone (17,21-dimethyl-19-nor-pregna-4,9-diene-3,20-dione; [ $\left.{ }^{3} \mathrm{H}\right] \mathrm{R} 5020 ;$ sp. act. $87.0 \mathrm{Ci} / \mathrm{mmol}$ ) and radioinert R5020 from New England Nuclear Corp. (Boston, MA); $\mathrm{Na}^{125} \mathrm{I}(13.9 \cdots 15 \mathrm{mCi} / \mu \mathrm{g}$ ) 
from Amersham Corp. (Arlington Heights, IL); diethystilboestrol (DES), calf thymus DNA, bovine serum albumin (BSA), ovine prolactin ( $<0.5 \% \mathrm{GH}$ contamination as determined by radioimmunoassay), progesterone, and Norit A from Sigma Chemical Co. (St Louis, MO); Ready-Solv EP scintillation cocktail from Beckman Instruments, Inc. (Fullerton, CA); Hanks' Balanced Salt Solution (HBSS) from Gibco (Grand Island, NY); Dextran-70 from Pharmacia Fine Chemicals, Inc. (Piscataway, NY); Spectra Por 3 dialysis tubing from Fisher Scientific (Atlanta, GA); and ovine growth hormone (AFP-4586; $<2.0 \%$ prolactin contamination as determined by radioimmunoassay) from the National Hormone and Pituitary Program, NIADDK. For the radioimmunoassay (RIA) procedures, reagents were acquired from the following sources: ovine prolactin (AFP-4328C), ovine prolactin antiserum (rabbit) (AFP-973269), rabbit prolactin (AFP-1974-C), and the antiserum (rat) to rabbit prolactin (AFP-18102677) from the National Hormone and Pituitary Program, NIADDK; goat anti-rat IgG $(\mathbf{H}+\mathbf{L})$ from Jackson ImmunoResearch Laboratories, Inc. (Avondale, PA); and Pansorbin (Staphylococcus aureus cells, Cowan I strain) from Behring Diagnostics (La Jolla, CA). All other chemicais purchased were of standard reagent grade.

Animal treatment. Adult $(3.6-4.5 \mathrm{~kg})$ virgin New Zealand White rabbits were housed individually for 3 weeks before experimentation. The oestrous condition of these animals was verified by the presence of mature ovarian follicles at the time of laparotomy (oestrous controls, $\mathrm{N}=10$ ), or at the time of ovariectomy. At a minimum of 12 weeks after ovariectomy, 11 animals were used as experimental controls, i.e. injected with phosphate-buffered saline (PBS; $\mathrm{pH} 7 \cdot 2 ; 1 \mathrm{ml} / 24 \mathrm{~h}$ for 5 days) followed by corn oil for 4 days. Thus control animals received the maximum number of injections. The remaining ovariectomized animals were divided into 5 treatment groups (4-12 animals/ group). In Group I, rabbits received subcutaneous injections of prolactin in PBS every $24 \mathrm{~h}$ for 5 days. In studies in which uteroglobin was measured, animals received $1.0 \mathrm{mg}$ prolactin daily; in those in which receptor concentrations were measured, animals received $0.5 \mathrm{mg}$ prolactin daily. In Group 2, the rabbits were treated with prolactin for 5 days followed by progesterone $(3 \mathrm{mg} / \mathrm{kg} / 24 \mathrm{~h})$ for 4 days. In Group 3, rabbits were treated with progesterone alone for 4 days. In Group 4, rabbits were treated with growth hormone $(1.0 \mathrm{mg})$ in PBS every $24 \mathrm{~h}$ for 5 days. In Group 5, the rabbits were treated with growth hormone for 5 days followed by progesterone for 4 days.

Uterine fluid collection and analysis. Uterine fluid samples were collected $6 \mathrm{~h}$ after the last injection, dialysed and concentrated by lyophilization (Daniel et al., 1984). The total protein concentration of each sample was determined according to Lowry et al. (1951) using BSA as the standard.

One-dimensional immunodiffusion with a single antibody-antigen system in tubes as described by Oudin (1952) was used to determine the uteroglobin concentration of each sample as previously described by Daniel et al. (1984). The data were analysed statistically by one-way ANOVA and Student-Newman-Keuls (SNK) tests. Significance was tested at levels of 0.05 and 0.01 for the ANOVA and at 0.05 for the SNK tests.

Tissue preparation for receptor assays. Uterine endometrium was scraped from underlying myometrium, weighed and homogenized $(100 \mathrm{mg} / \mathrm{ml})$ in ice-cold buffer $(50 \mathrm{~mm}$-Tris- $\mathrm{HCl}, 1 \mathrm{~mm}$-disodium ethylenediamine tetraacetic acid and $12 \mathrm{~mm}$-monothioglycerol; $\mathrm{pH} 7.5$ ) containing $30 \%$ glycerol (v/v), with a Polytron PT-10 homogenizer (Brinkman Instruments, Westbury, NY). Aliquants $(100 \mu \mathrm{l})$ were reserved for DNA assay according to the method of Burton (1956) using calf thymus DNA as the standard. Cytosolic fractions and extracted nuclear pellets were prepared as previously described (Daniel et al., 1984), and assayed for total oestrogen and progesterone receptor concentrations.

Receptor assays. Aliquants $(200 \mu \mathrm{l})$ of cytosol and nuclear extracts were apportioned into test tubes containing $100 \mu \mathrm{l}$ of buffer $(10 \mathrm{~mm}$-Tris- $\mathrm{HCl}, 1 \mathrm{~mm}$-disodium ethylenediamine tetraacetic acid and $12 \mathrm{~mm}$-monothioglycerol; $\mathrm{pH} 7.5$ ) and increasing concentrations $(0.5-20.0 \mathrm{nM})$ of $\left[{ }^{3} \mathrm{H}\right]$-oestradiol or $\left[{ }^{3} \mathrm{H}\right] \mathrm{R} 5020$ (total binding). Parallel samples were incubated with 100-fold excess of DES or radioinert R5020 for evaluation of non-specific binding. Samples were incubated at $30^{\circ} \mathrm{C}$ for $3 \mathrm{~h}$ to measure total oestrogen receptor and at $4^{\circ} \mathrm{C}$ for $18-20 \mathrm{~h}$ to measure total progesterone receptor as previously described (Chilton et al., 1982). A single saturating dose assay was used when tissue samples were very small (Chilton $\&$ Key, 1984). For this assay, samples were incubated with a final concentration of $20 \cdot 0 \mathrm{nM}-\left[{ }^{3} \mathrm{H}\right]$ oestradiol $\pm 2 \cdot 0 \mu \mathrm{M}$-DES or $20 \cdot 0 \mathrm{nM}-\left[{ }^{3} \mathrm{H}\right] \mathrm{R} 5020 \pm 2 \cdot 0 \mu \mathrm{M}$-radioinert R5020.

Incubation was terminated by the addition of $300 \mu \mathrm{l}$ dextran-coated charcoal followed $4-5$ min later by centrifugation at $500 \mathrm{~g}$ for $3 \mathrm{~min}$. Radioactivity was measured in the supernatant. The concentration of total receptor was determined from Scatchard (1949) analysis of specific binding data (subtraction of non-specific binding from total binding). The unpaired Student's $t$ test was used for data analysis.

RIA for ovine prolactin. Arterial blood samples (10-15 $\mathrm{ml}$ ) were collected from the ear of each rabbit. All samples were allowed to clot at $4^{\circ} \mathrm{C}$ overnight. Sera were collected and stored frozen $\left(-20^{\circ} \mathrm{C}\right)$. The experimental system was optimized with an RIA for sheep prolactin in rabbit serum using the purified ovine prolactin (AFP-4328C) as antigen, and rabbit anti-ovine prolactin (AFP-973269) as the first antibody. Because we were measuring sheep prolactin in rabbit serum, Pansorbin was substituted (Frohman et al., 1979) for the second antibody (rabbit anti-ovine prolactin). Ovine prolactin was iodinated at $100 \mu \mathrm{g} / \mathrm{ml}$ with chloramine- $\mathrm{T}(4 \mu \mathrm{g} / \mu \mathrm{g}$ ovine prolactin). The labelled sheep prolactin was separated from free iodine by Sephadex G-25 column chromatography. Each fraction containing radiolabelled prolactin was evaluated for binding capacity. The fraction with the highest specific binding was then used in the assay. The sensitivity of the assay was $0.05 \mathrm{ng} / \mathrm{ml}$ serum. The intra- and inter-assay coefficients of variation were less than $4 \%$ and $13 \%$, respectively. Nine ovariectomized animals were placed in 3 treatment groups and given a subcutaneous injection of $0.05 \mathrm{mg}, 0.5 \mathrm{mg}$ or $1.0 \mathrm{mg}$ sheep prolactin in $1 \mathrm{ml}$ PBS, $\mathrm{pH} 7.4$. Animals were bled before injection and at intervals after injection. Serum samples were assayed in duplicate. 
RIA for rabbit prolactin. We developed an RIA for rabbit prolactin using the purified rabbit prolactin (AFP-1974-C) as antigen. The first antibody was rat anti-rabbit prolactin (AFP-18102677), and the second antibody was goat anti-rat IgG. Rabbit prolactin was iodinated at $100 \mu \mathrm{g} / \mathrm{ml}$ with chloramine- $\mathrm{T}(4 \mu \mathrm{g} / \mu \mathrm{g}$ rabbit prolactin). The labelled rabbit prolactin was separated from free iodine by Sephadex G-25 column chromatography and fractions containing iodinated prolactin were checked for binding capacity. The sensitivity of the assay was $0.05 \mathrm{ng} / \mathrm{ml}$ serum. All samples were evaluated in triplicate with a single assay.

Light microscopy. Segments ( $6 \mathrm{~mm}$ in length) of whole uteri were rinsed free of blood in HBSS and cut open along the mesometrial edge. Each piece of organ was pinned in a dish of fixative (3\% glutaraldehyde, $2 \%$ paraformaldehyde), until such time that it could be cut into $1 \mathrm{~mm}$ thick cross-sections. Each piece of organ was fixed overnight, dehydrated, embedded, and sectioned $(6 \mu \mathrm{m})$. Sections were stained with haematoxylin and eosin (Humason, 1967). Direct measurements of cross-sectional area of endometrium and whole uteri were made using a computerized image analyser (Bioquant II Image Analysis). Ratios of endometrial cross-sectional area (thickness) to whole uteri were calculated from 4 randomly selected sections/animal and values were expressed as a percentage. $T$-test matrices for unpaired group means were determined and probabilities calculated.

\section{Results}

Serum titres of sheep prolactin for the three treatment groups are summarized in Table 1. McNeilly \& Friesen $(1978 \mathrm{a}, \mathrm{b})$ have demonstrated that normal basal blood concentrations of prolactin in rabbits are $10-30 \mathrm{ng} / \mathrm{ml}$ increasing up to $200 \mathrm{ng} / \mathrm{ml}$ during the first 16 days of pregnancy. Therefore, either $0.5 \mathrm{mg}$ or $1.0 \mathrm{mg}$ could have been selected as the optimal dosage of sheep prolactin because serum titres remained elevated during the first $9 \mathrm{~h}$ of treatment, yet when superimposed on already existing rabbit prolactin titres (Table 2) the total serum prolactin concentration did not exceed maximal pregnancy levels. The treatment of does with either dosage resulted in elevated receptor concentrations; however, $1.0 \mathrm{mg}$ prolactin daily was required for enhanced uteroglobin secretion in the prolactin + progesterone-treated animals.

The collective results for uterine fluids from the animals in all treatment groups are presented in Table 2. Neither prolactin alone, nor growth hormone alone promoted uteroglobin production. Growth hormone + progesterone and progesterone alone stimulated low levels of uteroglobin production. However, prolactin + progesterone supported production of uteroglobin by longterm ovariectomized does comparable to values for 5-day pregnant animals (Daniel et al., 1984).

Scatchard analysis of $\left[{ }^{3} \mathrm{H}\right]$ oestradiol binding data, using the dextran-coated charcoal method for assay termination, resulted in a $K_{\mathrm{a}}=4.14 \pm 1.10 \times 10^{8} \mathrm{M}^{-1}(r=0.96)$ for cytosolic fractions, and a $K_{\mathrm{a}}=1.44 \pm 0.16 \times 10^{8} \mathrm{M}^{-1}(r=0.98)$ for $\mathrm{KCl}$-extracted nuclear fractions from endometrium of oestrous controls. Specific binding (mean \pm s.e.m.) was $11 \cdot 7 \pm 2 \cdot 1 \mathrm{pmol} / \mathrm{mg}$ DNA for cytosolic and $0.61 \pm 0.04 \mathrm{pmol} / \mathrm{mg}$ DNA for nuclear fractions (Table 3). Ovariectomy resulted in a $50 \%$ reduction in the concentration of cytosolic oestrogen receptor. Scatchard analysis of $\left[{ }^{3} \mathrm{H}\right] \mathrm{R} 5020$ binding data from the same oestrous animals indicated a $K_{\mathrm{a}}=5.6 \pm 3.3 \times 10^{8} \mathrm{M}^{-1}$

Table 1. Serum titres $(\mathrm{ng} / \mathrm{ml})$ of sheep prolactin in rabbits treated with sheep prolactin

\begin{tabular}{|c|c|c|c|}
\hline $\begin{array}{l}\text { Time (h) after } \\
\text { injection }\end{array}$ & $\begin{array}{l}\text { Group 1 } \\
(0.05 \mathrm{mg})\end{array}$ & $\begin{array}{l}\text { Group } 2 \\
(0.5 \mathrm{mg})\end{array}$ & $\begin{array}{l}\text { Group } 3 \\
\text { (1.0 mg) }\end{array}$ \\
\hline 0 & 0 & 0 & 0 \\
\hline 0.5 & $7 \cdot 1 \pm 1 \cdot 8$ & $27 \cdot 2 \pm 3 \cdot 9$ & $63.5 \pm 6.9$ \\
\hline $1 \cdot 0$ & $9 \cdot 7 \pm 4 \cdot 2$ & $53.9 \pm 1.8$ & $121.8 \pm 29.7$ \\
\hline $3 \cdot 0$ & $18.7 \pm 5.5$ & $38.6 \pm 5.5$ & $125.1 \pm 33.0$ \\
\hline $6 \cdot 0$ & $10.9 \pm 4.6$ & $25 \cdot 6 \pm 3.6$ & $83.0 \pm 22.8$ \\
\hline $9 \cdot 0$ & $8.7 \pm 3.8$ & $14.7 \pm 2.3$ & $32.7 \pm 4.7$ \\
\hline $12 \cdot 0$ & $4 \cdot 3 \pm 1 \cdot 0$ & $0.5 \pm 0.3$ & $12.7 \pm 4.9$ \\
\hline $24 \cdot 0$ & $3 \cdot 5 \pm 1 \cdot 3$ & 0 & $0.3 \pm 0.3$ \\
\hline
\end{tabular}

Values are expressed as mean \pm s.e.m. There are 3 animals in each treatment group and serum samples were assayed in duplicate. 
Table 2. Serum rabbit prolactin concentrations, endometrial thickness ( $\%$ of total uterus) and corresponding uteroglobin concentrations in oestrous, ovariectomized (Ovx), and Ovx rabbits treated with hormones

\begin{tabular}{|c|c|c|c|c|c|}
\hline Group & Treatment & $\begin{array}{l}\text { No. of } \\
\text { animals }\end{array}$ & $\begin{array}{c}\text { Serum } \\
\text { prolactin } \\
(\mathrm{ng} / \mathrm{ml})\end{array}$ & $\begin{array}{l}\text { Endometrial } \\
\text { thickness } \\
\text { ( } \% \text { of total) }\end{array}$ & $\begin{array}{c}\% \text { Uteroglobin/ } \\
\text { mg protein }\end{array}$ \\
\hline Control & Oestrous & 10 & $40 \cdot 9 \pm 7 \cdot 4$ & $35 \cdot 0 \pm 2 \cdot 0$ & 0 \\
\hline Control & Ovx & 11 & $43.3 \pm 6.4$ & $38.6 \pm 0.9$ & 0 \\
\hline 1 & $\underset{\text { prolactin }}{\text { Ovx }+}$ & 14 & $32 \cdot 5 \pm 5 \cdot 0$ & $45 \cdot 4 \pm 1 \cdot 6^{*}$ & 0 \\
\hline 2 & $\begin{array}{c}\text { Ovx }+ \\
\text { prolactin }+ \\
\text { progesterone } \\
\text { Ovx }+\end{array}$ & 4 & $22 \cdot 9 \pm 8 \cdot 0$ & $46 \cdot 5 \pm 3 \cdot 3$ & $45 \cdot 2 \pm 2 \cdot 4$ \\
\hline 4 & $\begin{array}{c}\text { progesterone } \\
\text { Ovx }+\end{array}$ & 12 & $36 \cdot 9 \pm 8 \cdot 4$ & $48 \cdot 0 \pm 2 \cdot 0$ & $16 \cdot 9 \pm 3 \cdot 6$ \\
\hline 5 & $\begin{array}{c}\text { growth hormone } \\
\text { Ovx }+ \\
\text { growth hormone }+ \\
\text { progesterone }\end{array}$ & 4 & & $41.4 \pm 2.5 \dagger$ & $22 \cdot 0 \pm 4 \cdot 3$ \\
\hline
\end{tabular}

Values are mean \pm s.e.m.

*Increased $(P<\overline{0.01})$ compared to control Ovx and equivalent to all treatments in which progesterone was included in the protocol.

†Unchanged $(P>0 \cdot 05)$ compared to control Ovx.

Table 3. Oestrogen and progesterone receptor concentrations in uteri of oestrous, ovariectomized (Ovx) and Ovx rabbits treated with hormones

\begin{tabular}{|c|c|c|c|c|c|}
\hline \multirow[b]{2}{*}{ Group } & \multirow[b]{2}{*}{ Treatment } & \multicolumn{2}{|c|}{$\begin{array}{l}\text { Oestrogen receptor } \\
\text { conc. (pmol/mg DNA) }\end{array}$} & \multicolumn{2}{|c|}{$\begin{array}{l}\text { Progesterone receptor } \\
\text { conc. (pmol/mg DNA) }\end{array}$} \\
\hline & & Cytosolic & Nuclear & Cytosolic & Nuclear \\
\hline Control & Oestrous & $11 \cdot 7 \pm 2 \cdot 1$ & $0.6 \pm 0.04$ & $9 \cdot 7 \pm 2.5$ & $0.4 \pm 0.09$ \\
\hline Control & Ovx & $5.5 \pm 0.1$ & $0.5 \pm 0.03$ & $1.4 \pm 0.3$ & $0.1 \pm 0.05$ \\
\hline 1 & $\begin{array}{c}\text { Ovx }+ \\
\text { prolactin }\end{array}$ & $14 \cdot 5 \pm 2 \cdot 0^{*}$ & $0.1 \pm 0.04$ & $5.5 \pm 0.9 *$ & $0.2 \pm 0.05$ \\
\hline 2 & $\begin{array}{l}\text { Ovx }+ \\
\text { prolactin }\end{array}$ & & & & \\
\hline 3 & $\begin{array}{l}+ \text { progesterone } \\
\text { Ovx }+\end{array}$ & $4 \cdot 3 \pm 0 \cdot 6$ & $0.2 \pm 0.03$ & $1 \cdot 8 \pm 0 \cdot 3$ & $0.02 \pm 0.0$ \\
\hline 4 & $\begin{array}{l}\text { progesterone } \\
\text { Ovx }+\end{array}$ & $7 \cdot 0 \pm 0.5$ & $0.3 \pm 0.06$ & $2 \cdot 1 \pm 0 \cdot 3$ & $0.3 \pm 0.02$ \\
\hline 5 & $\begin{array}{c}\text { growth hormone } \\
\text { Ovx }+\end{array}$ & $19 \cdot 8 \pm 5 \cdot 0^{*}$ & $0.6 \pm 0.3$ & $0.7 \pm 0.3$ & $0.5 \pm 0.3$ \\
\hline & $\begin{array}{l}\text { growth hormone } \\
+ \text { progesterone }\end{array}$ & $8 \cdot 3 \pm 1 \cdot 3$ & $0.5 \pm 0.05$ & $2.7 \pm 0.6$ & $0.04 \pm 0.0$ \\
\hline
\end{tabular}

Values are mean \pm s.e.m.

*Values are comparable $(P>0.05)$ to control oestrous values.

$(r=0.97)$ for cytosolic fractions, and a $K_{\mathrm{a}}=7.7 \pm 0.8 \times 10^{8} \mathrm{M}^{-1}(r=0.98)$ for KCl-extracted nuclear fractions. The specific binding was $9.7 \pm 2.5 \mathrm{pmol} / \mathrm{mg}$ DNA for cytosolic, and $0.4 \pm$ $0.09 \mathrm{pmol} / \mathrm{mg}$ DNA for nuclear fractions. Ovariectomy resulted in a decrease $(P<0.05)$ in the concentration of cytosolic and nuclear progesterone receptors (Table 3). Growth hormone treatment produced an increase $(P<0.05)$ in the concentration of cytosolic oestrogen receptor compared to ovariectomized controls, but failed to increase the concentration of progesterone receptor. Prolactin treatment resulted in an increase in the concentration of cytosolic oestrogen and progesterone receptors, such that the concentrations did not differ $(P>0.05)$ from the values for 

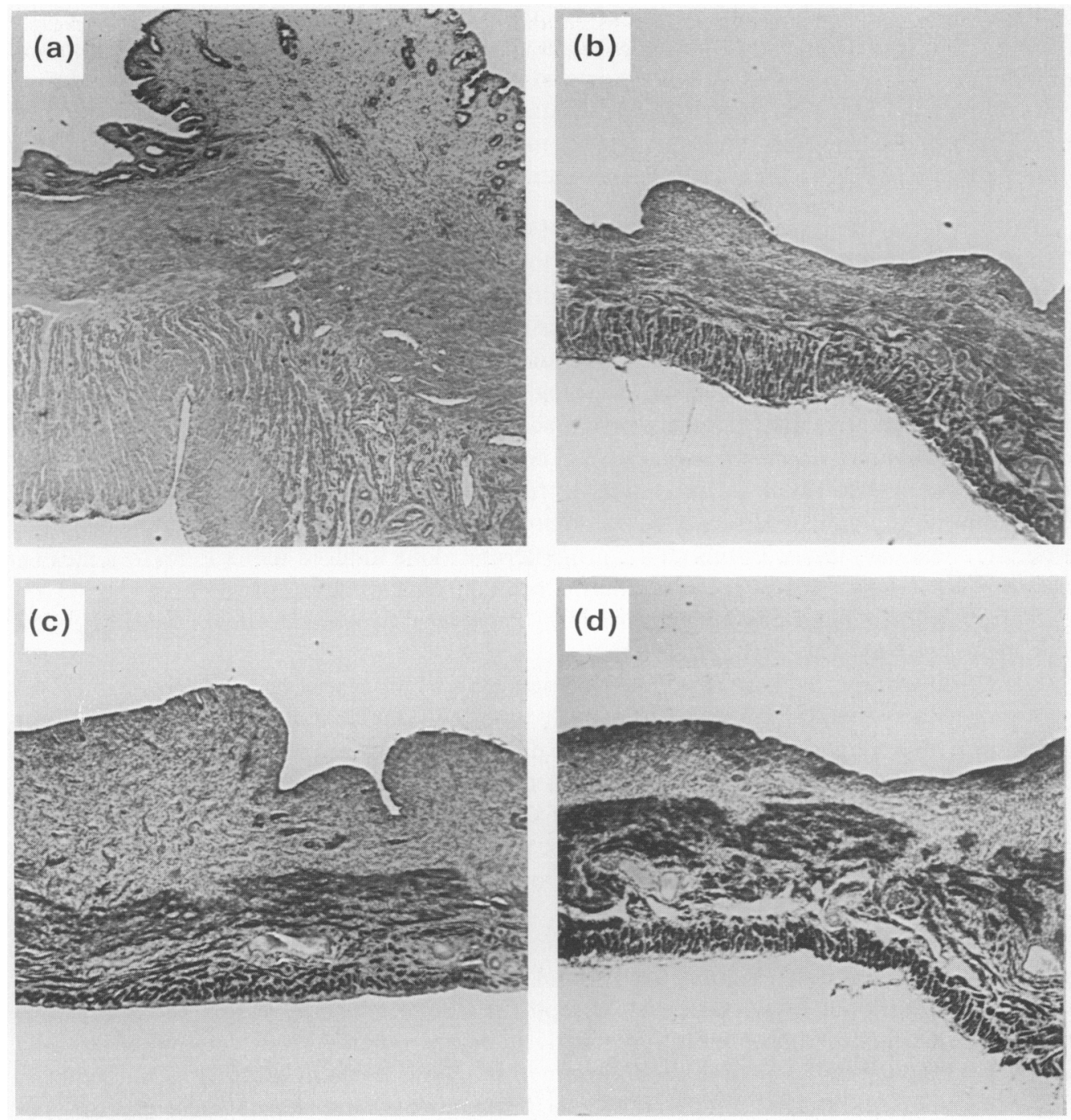

Fig. 1. Uterine tissue from an oestrous rabbit (a), an ovariectomized rabbit (b), and ovariectomized rabbit treated with prolactin (c), and an ovariectomized rabbit treated with growth hormone $(d)$. Note the prolactin-induced increase in endometrial thickness. $\times 30$.

oestrous controls. When animals were treated with prolactin + progesterone there was a 5-fold increase in the $K_{\mathrm{a}}$ value $\left(2 \cdot 15 \pm 0.47 \times 10^{9} \mathrm{M}^{-1}\right)$ for cytosolic oestrogen receptor, there was no comparable change in the $K_{\mathrm{a}}$ value when animals were treated sequentially with growth hormone + progesterone $\left(6.44 \pm 1.69 \times 10^{8} \mathrm{M}^{-1}\right)$. In all other treatment categories, progesterone injection resulted in the down regulation of receptor, such that the concentrations of oestrogen and progesterone receptors were not significantly $(P>0.05)$ different from those of ovariectomized controls.

As shown in Table 2, rabbit prolactin titres were comparable for all treatment categories. The ratios of endometrial thickness to whole uteri as calculated for all treatment groups from direct measurements are summarized in Table 2. Treatment with sheep prolactin caused an increase $(P<0.01)$ in the endometrial cross-sectional area compared to ovariectomized controls. In fact, the treatment of animals with prolactin alone produced an increase in the endometrial thickness 
comparable to that produced by progesterone alone or progesterone in combination with other hormones. However, the endometrial cross-sectional area of growth hormone-treated animals did not differ $(P>0.05)$ from that of ovariectomized controls. The differential effects of prolactin and growth hormone on uterine histology are illustrated in Fig. 1. Prolactin promoted a thickening of the uterine endometrium and an increase in glandular differentiation. Tissue from growth hormone-treated animals did not differ from tissue of ovariectomized controls.

\section{Discussion}

The effect of prolactin on the uterine response to progesterone is not somatogenic, i.e. it does not mimic the action of growth hormone. Optimal prolactin treatment results in increased endometrial cross-sectional area relative to whole uterine tissue, and the restoration of cytosolic oestrogen and progesterone receptor concentrations to oestrous control values. The sequential treatment of does with prolactin + progesterone results in uteroglobin secretion comparable to maximum values found on Day 5 of pregnancy (Daniel et al., 1984). In contrast, growth hormone treatment fails to increase the endometrial surface area, results in an increase in cytosolic oestrogen receptor but fails to restore the concentration of progesterone receptor. The sequential treatment of does with growth hormone + progesterone fails to stimulate uteroglobin secretion above background (progesterone alone) levels. In this study, progesterone alone induced uteroglobin to a mean concentration of $16 \cdot 9 \pm 3.6 \%$ of the total uterine protein. This value is only $35 \%$ of the maximum concentration for intact 5-day pregnant rabbits, and it is comparable to the previously published value of $14 \cdot 3 \pm 4 \cdot 6 \%$ (Daniel et al., 1984).

The $K_{\mathrm{a}}$ values reported here for cytosolic oestrogen and progesterone receptors are an order of magnitude greater than the values we previously reported (Daniel et al., 1984) for receptor immobilized on hydroxylapatite (HAP). The major differences between the two assay systems is the absence of glycerol in the assay in which we used HAP. This factor alone would account for the difference in equilibrium association constants $\left(K_{\mathrm{a}}\right)$ (Okulicz et al., 1983).

When prolactin is included in the treatment protocol, there is a 5 -fold increase in the $K_{\mathrm{a}}$ for cytosolic oestrogen receptor. However, when growth hormone is included in the protocol there is no concomitant increase in the $K_{\mathrm{a}}$. Leung \& Sasaki (1973) presented evidence of prolactinenhanced specific oestrogen binding in the rat uterus. These authors suggested that prolactin may potentiate specific oestradiol binding in any or all of the following ways: by increasing the cytosolic oestrogen receptor pool, by activation of a receptor precursor, by an increase in receptor synthesis, and/or by enhanced receptor integrity. Alternatively, receptor numbers are determined by using an equilibrium binding method and the equilibrium association constants are determined by the ratio of the association rate constant $\left(K_{\mathrm{a}}\right)$ to the dissociation rate constant $\left(K_{\mathrm{d}}\right)$, and so enhanced specific oestrogen-receptor binding could result from a prolactin-induced decrease in the $K_{\mathrm{d}}$, if the $K_{\mathrm{a}}$ remained unchanged.

Calculations of ratios of endometrial thickness to whole uteri for all treatment groups showed that prolactin treatment resulted in an increase $(P<0.01)$ in the endometrial layer compared to ovariectomized controls. In fact, the endometrial layer for prolactin-treated animals was comparable to that of animals treated with progesterone. Prolactin promotes a thickening of the uterine endometrium, an increase in glandular differentiation, and may alter the cellular composition of the endometrium (Chilton \& Daniel, 1985).

In this study we demonstrate that growth hormone and prolactin do not have the same effect on the rabbit uterine response to progesterone. It is concluded that prolactin acts to increase the concentration of progesterone receptor and thereby enhances uterine sensitivity to progesterone, which then acts to stimulate uteroglobin synthesis. Prolactin may also be involved in the events that regulate protein secretion.

We thank Ms Pamela B. Lonergan, Ms Karen Sullivan, Ms Sherry Taylor, Mr Christopher J. McAllister and Ms Scarlett G. Farney for technical assistance. This work was supported by NIH Grant HD20271. B.S.C. is a recipient of an NIH Research Career Development Award (HD-00704). 


\section{References}

Burton, K. (1956) A study of the conditions and mechanisms of the diphenylamine reaction for the colorimetric estimation of deoxyribonucleic acid. Biochem. J. 62, 315-323.

Chilton, B.S. \& Daniel, J.C. (1985) Influence of prolactin on DNA synthesis and glandular differentiation in rabbit uterine endometrium. Prolactin Basic and Clinical Correlates 1, 351-359.

Chilton, B.S. \& Key, T.L. (1984) Temporal effects of estradiol on progesterone receptor and glycoprotein synthesis in the epithelial-stromal complex of the rabbit endocervix. Biol. Reprod. 30, 231-238.

Chilton, B.S., Nicosia, S.V. \& Lyttle, C.R. (1982) Cytosol and nuclear estrogen and progesterone receptors in the rabbit endocervix. J. Steroid Biochem. 17, $363-369$.

Daniel, J.C., Jr. (1980) Factors influencing uteroglobin synthesis. In Steroid Induced Uterine Proteins, pp. 87-103. Ed. M. Beato. Elsevier/North Holland Biomedical Press.

Daniel, J.C., Jetton, A.E. \& Chilton, B.S. (1984) Prolactin as a factor in the uterine response to progesterone in rabbits. J. Reprod. Fert. 72, 443-452.

Frohman, M.A., Frohman, L.A., Goldman, M.B. \& Goldman, J.N. (1979) Use of protein A-containing staphylococcus aureus as an immunoadsorbent in radioimmunoassays to separate antibody-bound from free antigen. J. Lab. Clin. Med. 93, 614-621.

Humason, G.L. (1967) Animal Tissue Techniques, p. 136. W. H. Freeman \& Co., San Francisco.

Leung, B.S. \& Sasaki, G.H. (1973) Prolactin and progesterone effect on specific estradiol binding in uterine and mammary tissues in vitro. Biochem. Biophys. Res. Commun. 55, 1180-1187.

Lowry, O.H., Rosebrough, N.J., Farr, A.L. \& Randall, R.J. (1951) Protein measurement with the folin phenol reagent. J. biol. Chem. 193, 265-275.
MeNeilly, A.S. \& Friesen, H.G. (1978a) Heterologous radioimmunoassay for rabbit prolactin. Endocrinology 102, 1539-1547.

McNeilly, A.S. \& Friesen, H.G. (1978b) Prolactin during pregnancy and lactation in the rabbit. Endocrinology 102, $1548-1554$.

Norstedt, G. (1982) A comparison between the effects of growth hormone on prolactin receptors and estrogen receptors in rat liver. Endocrinology 110, 2107-2112.

Ohno, Y. (1982) Studies on the interaction of prolactin and estrogen in rabbit ovary and uterus. Acta obstet. gynaec. jap. 34, 252-260.

Okulicz, W.C., Boomsma, R.A., MacDonald, R.G. \& Leavitt, W.W. (1983) Conditions for the measurement of nuclear estrogen receptor at low temperature. Biochim. Biophys. Acta 757, 128-136.

Oudin, J. (1952) Specific precipitation in gels and its application to immunochemical analysis. In Methods in Medical Research, Vol. 4, pp. 335-378. Ed. A. C. Corcoran. Year Book Publishers, Chicago.

Posner, B.I., Kelly, P.A., Shiu, R.P.C. \& Friesen, H.G. (1974) Studies of insulin, growth hormone and prolactin binding: tissue distribution, species variation and characterization. Endocrinology 95, 521-531.

Scatchard, G. (1949) The attractions of proteins for small molecules and ions. Ann. N.Y. Acad. Sci. 51, 660-672.

Shiu, R.P. \& Friesen, H.G. (1974) Properties of a prolactin receptor from the rabbit mammary gland. Biochem. J. 140, 301-311.

Tamaya, T., Ohono, Y., Ide, N., Tsurusaki, T. \& Okada, H. (1980) Occurrence of prolactin binding sites in rabbit ovary and uterus. Japanese J. Fert. Steril. 25, $8-12$.

Received 29 July 1986 